American Journal of Agricultural and Biological Sciences 5 (3): 261-268, 2010

ISSN 1557-4989

(C) 2010 Science Publications

\title{
Chemical Profile of Sotol Analyzed by Solid Phase Microextraction-Gas Chromatography
}

\author{
Heliodoro de la Garza, Juan Buenrostro, María Reyes-Vega, Raúl Rodríguez, \\ Dolores G. Martinez and Cristobal N. Aguilar \\ Department of Food Science and Technology, \\ School of Chemistry, Universidad Autónoma de Coahuila, Blvd., \\ Venustiano Carranza Col. República 25280, Saltillo Coahuila, México
}

\begin{abstract}
Problem statement: Sotol is a distilled spirit made from Dasylirion spp., a plant (called sotol) that grows in the wilds of Northern Mexico and west Texas and New Mexico. This alcoholic beverage is produced in a similar process to the more common artisanal tequila and mescal. Sotol is also now beginning to achieve international recognition; however there are few commercial examples available, which are elaborated with poor quality and sensorial attributes un-defined. Approach: This is the first study which reported a chemical characterization of the main components of six commercial sotols, establishing the correlations among the samples and determining the similitude levels. Solid Phase Microextraction-Gas Chromatography (SPME-GC) was used to analyze the chemical compounds present in the sotols (Hacienda ${ }^{\mathrm{TM}}$, Mesteno $^{\mathrm{TM}}$, Coyamito, Los Cuates, un-aged Alacrán and rested Alacran). Results: From data obtained of the analysis of main components, a total of 25 chemical compounds were found to be related with six physicochemical characteristics of sotol, explaining $66.1 \%$ of the total variance. Rested Alacran and un-aged Alacran sotols were related by the high content of propionic acid, undecanoic acid, acetic acid, buthanol and furfural and by the low contents of phenyl ethanol, decanoic acid and ethyl dodecanoic acid. Mesteno ${ }^{\mathrm{TM}}$ and Coyamito sotols presented an opposite chemical composition. Hacienda ${ }^{\mathrm{TM}}$ sotol contains high concentration of propanol, ethyl acetate, methyl butanol, hexadienal and low levels of ethyl decanoic acid and naftalene, chemical compounds do not found in Los cuates sotol. Conclusion: This study revealed for first time the chemical profile of the sotol demonstrating the necessity to improve the elaboration process of this alcoholic beverage to offer a Mexican product of high quality in the global market.
\end{abstract}

Key words: Sotol, SPME-GC, chemical compounds, alcoholic beverage

\section{INTRODUCTION}

Information of chemical composition of an important Mexican alcoholic beverage called sotol, is scarce and confuse, limiting its commercialization in the global market. Chemical composition of a product determines its quality and it is important criterion to be considered during the elaboration process. Sotol is distilled liquor obtained from the fermentation of rectified musts from heads of Dasylirion cedrosanum and/or D. duranguensis. During the fermentation, native yeasts convert the fructans and free sugars into ethanol (Robertfroid and Delzenne, 1998). Then, fermented liquid is distilled in rustic equipments to be bottled and commercialized. Three types of sotols are currently commercialized (un-aged, rested and anejo).
In the case of maturated sotols, barrels of encino, oak, acacia, Mexican beech and fresno are commonly used.

From the pre-Hispanic era, in the North of Mexico and the South of United States, fermented sotol was consumed as food by natives. With the arrival of Spanish colonizers, distillation was introduced in the process, obtaining a liquor called sotol or sereque (De la Garza-Toledo et al., 2008). This process has remained without changes, for this reason the beverage is impure and presents low quality. New conditions of market for this popular drink are changing the form of elaboration of the product, for this reason the standardization of the process is a necessity.

Conversion of fermentable sugars to alcohol is given in a spontaneous fermentation of sotol musts, exhibiting a population succession of microorganisms.

Corresponding Author: Cristobal N. Aguilar, Department of Food Science and Technology, School of Chemistry,

Universidad Autónoma de Coahuila, Blvd., Venustiano Carranza Col. República 25280, Saltillo

Coahuila, México Tel: +52(844)4169213 Fax: +52(844)439 0511 
During the first period of the fermentation process, the yeasts (Kloeckera sp., Hanseniospora sop, Kluyveromyces spp, Zygosaccharomyces sp. and Torulopsis sp.) hydrolyze the fructans to fermentable sugars. In the second period of the fermentation, Brettanomyces sp. and Kluyveromyces marxianus produce low levels of alcohol. At the final period of the process, Saccharomyces cerevisiae is the predominant yeast (Beech and Davenport, 1970; De la GarzaToledo et al., 2008). This population diversity contributes to the sensorial attributes of the sotol (Berry and Watson, 1991; Fleet and Heard, 1990; Heard and Fleet, 1985), including disagreeable flavors and aromas (Heresztyn, 1986; Ribereau-Gayon et al., 2000). During the fermentation process of yeasts, the levels of ethanol increase associated to the accumulation of products that inhibit the growth of yeast, among which are 2-phenyl ethanol, 1-propanol and 2-buthanol (Dieguez et al., 2002; De Leon-Rodriguez et al., 2006)

The objective of this study was to determine the chemical profiles of commercial sotols, establishing the correlation among them and associating the physicochemical properties to the main groups of chemical compounds found these samples.

\section{MATERIALS AND METHODS}

Six commercial sotols were bought in shops and regional producers of the States of Chihuahua (Hacienda $^{\mathrm{TM}}$, Mesteno ${ }^{\mathrm{TM}}$, Coyamito), Coahuila (Los Cuates) and Durango (un-aged Alacran and rested Alacran). These liquors were measured contents of dry matter and ash and its composition was determined by chemical and chromatographic methods (Lachenmeier et al., 2009).

Determination of dry matter: Dry matter was evaluated according to Mexican Official Norm reported by De la Garza-Toledo et al. (2008). At a constant mass capsule was added $25 \mathrm{~mL}$ of the sample, which was then completely evapored in a water bath, after that the capsule was placed in a oven $\left(105^{\circ} \mathrm{C}\right)$ for $1 \mathrm{~h}$. The amount of dry matter was calculated as follows:

$$
\mathrm{Es}=\frac{\mathrm{Me}(\mathrm{g})-\mathrm{mv}(\mathrm{g}) \times 1000 \mathrm{~mL}}{\mathrm{~V}(\mathrm{~mL})}
$$

Where:

$$
\begin{aligned}
& \mathrm{Es}=\text { Quantity of dry extract expressed in } \mathrm{g}^{-1} \\
& \mathrm{Me}=\text { Mass of the capsule plus dry matter in } \mathrm{g} \\
& \mathrm{mv}=\text { Mass of the empty capsule in } \mathrm{g} \\
& \mathrm{V}=\text { Volume of the simple used in } \mathrm{mL}
\end{aligned}
$$

Determination of ash: The capsule containing the dry residue was placed in the muffle $\left(525^{\circ} \mathrm{C}\right)$ for $20 \mathrm{~min}$, was removed from the muffle and allowed to cool in a desiccators at room temperature (around $4 \mathrm{~h}$ ), then determinate the mass and this procedure was repeated until constant mass was achieved. The amount of ash was estimated using the following expression:

$$
\mathrm{C}=\frac{(\mathrm{MC}-\mathrm{My}) \times 10^{6}}{\mathrm{~V}}
$$

Where:

$\mathrm{C}=$ Amount of ash, $\mathrm{mg} \mathrm{L}^{-1}$,

$\mathrm{MC}=$ Mass of the capsule plus ash, $\mathrm{g}$

My $=$ Mass of the empty capsule, $\mathrm{g}$

$\mathrm{V}=$ Volume of the simple used, $\mathrm{mL}$

Determination of contents of alcohol expressed in percent by volume: In a volumetric flask was measured the sample specified in the norm, at a temperature of $20^{\circ} \mathrm{C}$, glass beads were added as well as $2.5 \mathrm{~mL}$ of solution $6 \mathrm{~N} \mathrm{NaOH}$ and distilled to about $0.5 \mathrm{~cm}$ below the capacity mark, filling with distilled water to reach the mark and homogenized and the temperature was measured by transferring the distilled to a test tube, which introduced the alcoholmeter and reading was obtained.

Solid Phase Micro Extraction (SPME) for volatile compounds: Volatile compounds were analyzed by SPME-GC (Lopez, 1999; Pena-Alvarez et al., 2004). Sample taken was with a fused silica fiber coated with an adsorbent material, the sample was placed in a sealed vial and the septum was perforated, exposing the adsorbent material with the sample (stirring) for a period of time ranging from 15-30 min, pulled the adsorbent material and pulled the syringe from the vial (SPME syringe, for highly volatile compounds: Carbowax/Dinny benzene (CW/DVB)). The gas chromatograph injector was drilled with the syringe and the adsorbent material and the analytes were exposed to temperature, which were desorbed in the injector, where total desorption. For best results of extraction, first the SPME injection syringe was activated for 48 hrs at a temperature of $210^{\circ} \mathrm{C}$ in the gas chromatograph.

For the analysis of Sotol was injected into a gas chromatograph HP 4890 fitted with mass selective detector HP 5972 and a column Freed Fasttid Acid Phace (HPFFAP) at $40^{\circ} \mathrm{C}$ for $3 \mathrm{~min}$ and the temperature was increased in a ratio of $3^{\circ} \mathrm{C} \mathrm{min}^{-1}$ up to $180^{\circ} \mathrm{C}$ after 
the temperature was increased by a ratio of $6^{\circ} \mathrm{C} \mathrm{min}^{-1}$ up to $180^{\circ} \mathrm{C}$.

Qualitative Analysis of the chromatographic peak identification of homologous series (Kovacs retention indices): This method is based on assigning a particular value of circumvention for each compound defined based on a series hydrocarbon (n-paraffins) which is independent of the instrumental factors. The retention indices of any compound is equal to 100 times the carbon number of a hypothetical normal paraffin, which adds to the retention time of the compound of interest in relation to circumvention that occurs between 2 n-paraffins. Therefore in the same type might set comparisons.

Experimental design and statistical analysis: A completely randomized design was used in the present study. Statistical analysis of data included ANOVA and a comparison of mean values (Tukey's test) using the SAS/STAT.

\section{RESULTS}

In an initial phase, six sotols from different regions were subjected to physicochemical analysis. Results are summarized in Table 1 indicating that although all samples meet the parameters of the Mexican Official Norm of Sotol, variations exist between some products and others, mainly in the $\mathrm{pH}$ values and content alcohol. According to statistical analysis, we found no significant differences the liquors, for the variables $\mathrm{pH}$, dry matter, density and ash content.

Samples also were analyzed by gas chromatography with SPME system to detect volatile compounds of distilled beverages (Table 2). It should be noted that this work is a pioneer in identifying the main compounds present in sotol, allowing him this characteristic that makes it different from other distillates. Specific compounds were identified according to the Kovacsvalue and compared the results in a digital library.

Table 1: Physicochemical profiles of commercial sotols

\begin{tabular}{|c|c|c|c|c|c|c|c|}
\hline & Coyamito & Cuates & Un aged-Alacran & Rested Alacran & Hacienda & Mesteno & Average \\
\hline Alcohol (\%) & 46.00 & 39.55 & 40.00 & 36.00 & 38.16 & 38.18 & 39.55 \\
\hline $\mathrm{pH}$ & 4.95 & 4.96 & 4.92 & 5.05 & 5.50 & 4.53 & 4.99 \\
\hline Density $\left(\mathrm{mg} \mathrm{mL}^{-1}\right)$ & 0.94 & 0.93 & 0.94 & 0.95 & 0.94 & 0.94 & 0.94 \\
\hline Dry matter $\left(\mu \mathrm{g} \mathrm{L}^{-1}\right)$ & 1928.33 & 937.78 & 586.42 & 448.84 & 942.47 & 920.15 & 0.96 \\
\hline $\operatorname{Ash}\left(\mu \mathrm{g} \mathrm{L}^{-1}\right)$ & 1.57 & 0.38 & 0.57 & 0.38 & 0.35 & 0.35 & 0.60 \\
\hline
\end{tabular}

Table 2: Chemical compounds and concentration $\left(\mathrm{mgmL}^{-1}\right)$ identified by SPME-GC in commercial sotols

\begin{tabular}{|c|c|c|c|c|c|c|}
\hline Compound & Coyamito & Cuates & Un aged-Alacran & Rested Alacran & Hacienda & Mesteno \\
\hline Methanol & 230.650 & 105.990 & 296.320 & 295.550 & 276.460 & 102.376 \\
\hline Ethyl acetate & 1.179 & 0.000 & 0.000 & 0.000 & 447.240 & 2.179 \\
\hline Ethanol & 790.700 & 1713.75 & 1295.300 & 1303.600 & 10841.300 & 769.700 \\
\hline Propanol & 0.599 & 0.408 & 2.939 & 0.700 & 11.498 & 0.499 \\
\hline 1-butanol & 1.866 & 2.046 & 80.710 & 138.750 & 0.833 & 1.466 \\
\hline \multicolumn{7}{|l|}{ 2-methyl } \\
\hline Propanol & 0.379 & 0.324 & 85.277 & 85.277 & 66.563 & 0.279 \\
\hline 3-hydroxy butanol & 0.988 & 0.000 & 0.425 & 0.747 & 0.648 & 0.788 \\
\hline 3-methyl 1-butanol & 8.798 & 0.000 & 0.000 & 0.000 & 61.552 & 8.781 \\
\hline Acetic acid & 6.563 & 109.366 & 364.221 & 422.800 & 13.681 & 5.613 \\
\hline Propionic acid & $\mathrm{X}$ & X & X & X & $\mathrm{X}$ & $\mathrm{X}$ \\
\hline 2-4-hexadianol & 0.174 & 0.269 & 0.000 & 0.123 & 0.772 & 0.074 \\
\hline Octanoic acid & $\mathrm{X}$ & $\mathrm{X}$ & $\mathrm{X}$ & $\mathrm{X}$ & $\mathrm{X}$ & $\mathrm{X}$ \\
\hline Propanoic acid (2-hydroxy- ethyl ester) & 0.185 & 0.716 & 1.706 & 1.931 & 0.859 & 0.166 \\
\hline Octanoic acid (ethyl ester) & 3.223 & 0.000 & 0.000 & 2.025 & 4.043 & 2.113 \\
\hline Nonanoic acid (ethyl ester) & 0.405 & 0.000 & 0.000 & 1.767 & 0.371 & 0.445 \\
\hline Decanoic acid (ethyl ester) & 5.444 & 4.507 & 2.450 & 1.346 & 0.399 & 1.554 \\
\hline Undecanoic acid (ethyl ester) & 2.474 & 0.000 & 0.000 & 28.465 & 0.389 & 0.000 \\
\hline Dodecanoic acid (ethyl ester) & 2.429 & 0.000 & 0.097 & 0.558 & 0.998 & 0.429 \\
\hline Decanoic acid (ethyl ester) & 2.118 & 0.000 & 0.458 & 0.332 & 1.177 & 1.020 \\
\hline 1-methyl-4(1-methyl ethylene) ciclohexanone & 3.660 & 16.095 & 2.575 & 6.379 & 149.131 & 3.560 \\
\hline Acetate de 3-methyl 1-butanol & 1.923 & 0.609 & 15.960 & 15.960 & 10.666 & 1.903 \\
\hline Naphthalene & 1.411 & 2.500 & 2.659 & 0.953 & 0.820 & 0.410 \\
\hline 2-methyl naphthalene & 0.102 & 0.000 & 0.000 & 0.000 & 0.276 & 0.102 \\
\hline Phenyl ethanol & 0.987 & 0.308 & 0.000 & 0.237 & 0.325 & 0.743 \\
\hline Furfural & 0.870 & 0.345 & 2.297 & 1.435 & 0.452 & 0.301 \\
\hline
\end{tabular}

Note: X: Not detected 


\section{DISCUSSION}

One characteristic of these distillates is having a very low content in aldehydes (Total aldehydes = acetaldehyde +0.373 acetal). This suggest in principle that the fermentation of the dough is fairly pure distilled and/or giving a good distillation separating the heads. This is confirmed with relatively low values of ethyl acetate.

We found a wide variation in the characteristic organic compounds present in this beverage, since in some sotol only found that ranges from $2.65-19.7 \%$ of this drink as the process goes from artisanal to industrial, taking little care in the quality requirements.

The artisanal sotols have higher propanol than isobutanol, possibly by bacterial action. However in a study on the microbiology of fermentation was found that there aren't great presence of bacteria and this, coupled with that is distilled immediately after the finish of fermentation, makes the final distillate seems fairly pure.

Methanol is a product of the metabolism of yeast; however, their presence in fermented beverages is related to the concentration of pectin and pectin methyl esterase activity. Methanol does not pay a role in the aroma of cider. The methanol content is within the norm, possibly caused by rapid distillation and that the mass is sufficiently liquid (low hexanols values) due to the volume of water added. Moreover, subjecting a pineapple concoction, the action of enzymes responsible (pectin methyl esterase) can be extremely limited (Dieguez et al., 2002). It is possible some sotols have been cut with neutral alcohol, given that they have low contents of volatile compounds.

The volatile components of sotols are formed by higher aliphatic and aromatic alcohols such as 1propanol, isobutanol, isoamyl and amyl alcohol, 2phenyletanol, etc. The values of 2-butanol are low. This may be caused by the distillation is done soon, since the fermentation is finished, so there is little deterioration due to lactic acid bacteria. The higher alcohols are formed during the fermentation process for amino acid consumption by yeast and its proportion is related to the distillation process. The 2-phenylethanol is associated with fragrant floral aromas and its presence is favorable in the flavor on the brandy, while higher alcohols such isoamyl and amyl define complex flavor of fermented beverages, provides they are present in moderate amount. The 1-butanol is a compound that is produced in a small quantity by yeast during fermentation of juice (Dieguez et al., 2002).

Hexenols are low, possibly due to little time in contact with the liquid-solid mass before distilling. The 2-phenylethanol is a product of queues, like ethyl lactate. The 2, 4-hexadienol is a flavoring agent (De Leon-Rodriguez et al., 2006).

The synthesis of aliphatic esters by yeast is of greater industrial interest as these compounds determine the fruity aroma of fermented beverages. Esters represent the largest group of aromatic compounds in fermented alcoholic beverages. The ethyl acetate esters is one of the highest concentration on fermented drinks, its concentration in wine for example is related to the elaboration process and the strain of yeast used in fermentation (Dieguez et al., 2002)

The contents in higher alcohols acetates (rose, pineapple, banana) are also low. This is because there is a little acetic, consistent with the low values of ethyl acetate present in the sotol. Furthermore, the content in ethyl esters is not very high. Carboxylic acids such as acetic acid are produced by the indigenous flora of apiculate yeasts during the early stage of fermentation.

The volatile fatty acid content (causing rancid cheese past, rancid) are low, which confirms that no major degradation of the mass to distill by bacteria (mainly of the genus Clostridium are those giving rise to these volatile acids). During the anaerobic fermentation by yeast, as it increases the concentration of ethanol also increases the concentration of growthinhibiting products, such as 2-phenylethanol, 1propanol and 2-butanol.

Correlations between compounds of different brands of stool: As ethanol concentration increases the concentration of products of growth inhibition of yeast, such as 2-phenylethanol, 1-propanol and 2-butanol. Importantly, the undecanoic acid characteristic compound present of agaves and nolinaceas, negatively correlated with the ethanol content (which can be added to adulterate the product), also with hexadienol (which despite being a product flavoring, it is not characteristic of the agaves and neolinaceas). So does negatively with ethyl acetate, methyl butanol and hexandienol. Then, in Table 3 shows the correlation of values by groups of compounds.

Compounds that have the greatest effects on the characteristic aroma of sotol are:

- Alcohols: Ethanol, methanol, glycerol, higher alcohols (propanol, isobutanol, 1-propanol, 2methylpropanol, butanol, methyl butanol, amyl alcohol, 1-hexanol, 1-hexanol, 2-phenyl ethanol)

- Volatile acids: Acetic, propionic, butyric, octanoic, undecanoic and dodecanoic 
Am. J. Agri. \& Biol. Sci., 5 (3): 261-268, 2010

Table 3: Linear Correlations (LC) between values for groups of compounds

\begin{tabular}{|c|c|c|c|c|c|}
\hline Compound & Vs compound & LC & Compound & Vs compound & LC \\
\hline \multicolumn{6}{|l|}{ Alcohols } \\
\hline Methanol & Etildecanoic acid & + & Ethanol & Ethyl acetate & + \\
\hline Ethanol & Methyl butanol & + & Ethanol & Propanol & + \\
\hline Ethanol & Hexadianol & + & Ethanol & Undecanoic acid & - \\
\hline 2-methyl propanol & 3-methyl-1-butanol & + & 2-methyl propanol & Propionic acid & + \\
\hline 1-butanol & Methyl methyl ciclohexanone & + & 3-hydroxybutanol & Ethyldecanoic acid & + \\
\hline 2-methylpropanol & Methylbutanol & + & 2-methylpropanol & Propionic acid & + \\
\hline 3-methyl-1-butanol & Propanol & + & 3-methyl-1-butanol & 2,4-hexadienol & + \\
\hline 2,4-hexadienol & Cyclohexanone & + & 2,4-hexadienol & Propanol & + \\
\hline 2,4-hexadienol & Undecanoic acid & - & & & \\
\hline \multicolumn{6}{|l|}{ Acids } \\
\hline Acetic acid & Butanol acetate acid & + & Acetic acid & Butanol & + \\
\hline Acetic acid & Propionic acid & + & Acetic acid & Furfural & + \\
\hline Acetic acid & Phenyl ethanol & - & Propionic acid & Methyl propanol & + \\
\hline Propionic acid & Butanol & + & Propionic acid & Methyl butanol acetate & + \\
\hline Octanoic acid & Methylnaphthalene & + & Octanoic acid & Phenyl ethanol & + \\
\hline Nonanoic acid & Methyl ethylene & + & Nonanoic acid & Cyclohexanone & + \\
\hline Undecanoic acid & Ethyl acetate & - & Undecanoic acid & Methyl butanol & - \\
\hline \multirow{2}{*}{\multicolumn{6}{|c|}{ Esters }} \\
\hline & & & & & \\
\hline Ethyl acetate & Methyl butanol & + & Ethyl acetate & Hexodianol & + \\
\hline Ethyl acetate & Ethyldecanoic acid & + & Ethyl acetate & Propanol & + \\
\hline Ethyl acetate & Methyl butanol & + & Methyl butanol Acetate & Methyl propanol & + \\
\hline Methyl butanol acetate & Butanol & + & Methyl butanol Acetate & Propionic acid & + \\
\hline $\begin{array}{l}\text { Decanoic acid ethyl ester } \\
\text { Cvclic }\end{array}$ & Methanol & + & Decanoic acid ethyl ester & Hydroxybutanol & + \\
\hline Cyclohexanone & Nonanoic acid & + & Cyclohexanone & Propionic acid & + \\
\hline Cyclohexanone & Acetic acid & + & & & \\
\hline \multicolumn{6}{|l|}{ Naphthalenes } \\
\hline Naphthalene & Not correlate with anything & & Methylnaphthalene & Octanoic acid & + \\
\hline Methylnaphthalene & Phenyl ethanol & + & & & \\
\hline \multicolumn{6}{|l|}{ Aromatic } \\
\hline Phenyl ethanol & Acetic acid & - & & & \\
\hline
\end{tabular}

- Aldehydes: Acetaldehyde, propanal, butanal, isobutanal

- Esters: methyl acetate, ethyl acetate, benzyl acetate, ethyl lactate, ethyl caprylate, ethyl benzoate, benzaldehyde, isoamyl acetate, decanoic acid ethyl ester

- Polyphenols: Colorants substances of stools pineapple and tannins

Besides many minor compound include benzyl alcohol, phenyl alcohol, 3-hexen-1-ol, 6,9pentadecadien-1-ol, ethyl butanoate, ethyl pentanoate, ethyl hexanoate, ethyl octanoate, ethyl decanoato, ethyl dodecanoate, ethyl hexadecanoate, 3-hydroxy-2butanone, hexanoic acid, 2-pentifurano, furfural, 5methyl-furfuraldehyde.

The aroma is mainly responsible for the alcohols of more than three carbons and the ethyl esters and terpenes and long-chain fatty acids. Among the most abundant compounds in the sotol include furfural, naphthalene and 1-methyl naphthalene. Also along with other minor compounds contribute to define the characteristic aroma of sotol and mescal.
Identifying the group most important chemical compounds that characterize the different brands of stool: The analysis of the results was conducted from standardized data and considered only the first two principal components, since they account for $66.1 \%$ of the total variance (Fig. 1). The highest absolute value coefficients correspond to the variables that have more weight to characterize the different brand of sotol. Variables propionic acid and dry matter has a strong influence to chemically characterize the sotol. A shaft level two, the variables are separated more ethyl acetate and ethyl decanoic acid, opposing each other. The variables c1-methyl-4 (1 methyl) and ethyl undecanoic acid, \% alcohol, c2-fluorocarboxidial and ash, c3methyl butanol and c2-4 hexadienal vectors showed fewer angles between them indicating that the association among them. It can be seen at CP1, the first vector has positive and negative elements. The Rested Alacran and un-aged Alacran are characterized by higher proportion of propionic acid, undecanoic acid, butanol, acetic acid, furfural, nanonoic ethyl acid and low amounts of decanoic ethyl acid, dodecanoic acid and phenyl ethanol. 
Am. J. Agri. \& Biol. Sci., 5 (3): 261-268, 2010

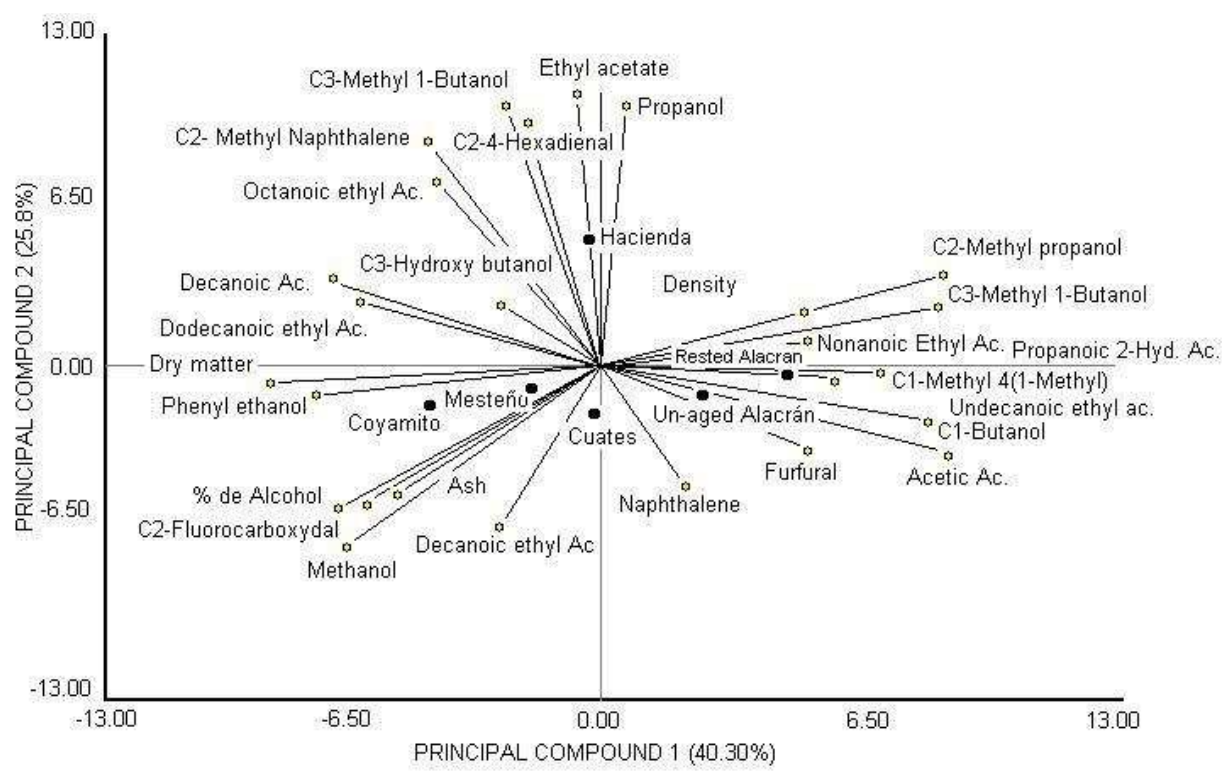

Fig. 1:Biplot obtained from Principal Component Analysis (PCA). The ranking is produced by 25 chemical compounds and six physicochemical characteristic of sotol

In contrast, the Mesteño and Coyamito sotols were characterized by a totally different composition. In terms of composition, La Hacienda was the opposite of Los Cuates, where the first was characterized by having a greater concentration of propanol ethyl acetate, methyl butanol and low concentrations of decanoic ethyl acid and naphthalene.

These 25 main chemical compounds found in the six sotol can characterize related this distilled beverages of Mexican origin, since there are no studies related to this drink, there are only reports on other distilled beverages such as tequila, mezcal and pulque. The main chemical families found are acetals, carboxyl acids, alcohols, carbonyls, esters, phenols, furans, lactones and terpenes (Gutierrez-Coronado et al., 2007).

In the production of tequila, we have identified over 240 compounds in the exudates of pineapples cooked Agave tequilana Weber var. Blue, especially acids, alcohols and furans, followed by aldehydes, ketones, aromatics compounds, terpenes, pyrans, nitrogen compounds and sulfur compounds (MancillaMargalli and Lopez, 2002). The compounds have been identified mezcal classified as acetals, carboxylic acids, alcohols, ketones, aldehydes, esters, phenols and terpenes, finding a greater presence of alcohols, esters and acids (De Leon-Rodriguez et al., 2006, MolinaGuerrero et al., 2007). In the case of pulque have identified nine volatile compounds: acetaldehyde, ethyl acetate, methanol, ethanol, propanol, 2-butanol, isobutanol, amyl alcohol and allyl alcohol (GutierrezCoronado et al., 2007)

Association between six sotol commercial liquors based on the chemical composition: The liquor Rested Alacran an un-aged Alacran were grouped (Fig. 2) as expected, since they are produced in the same factory and from the same species of Dasylirion, their differences lie in the aging in oak barrels, which can alter the chemical composition f Rested Alacran. This group clearly differs from other beverages; the most reasonable explanation is that these liquors are manufactured in Durango State, a region dominated by species of sotol Dasylirion duranguensis which they may confer a distinct chemical composition from other liquors which are elaborated from $D$. cedrosanum.

Mesteno and Coyamito liquors formed another group closely related, these two beverages are produced in different companies in the state of Chihuahua, as similar composition suggests that similar processing method are followed. Los Cuates and La Hacienda liquors were associated more with Coyamito and Mesteno group; this is explained by the same kind of sotol used for the manufacture of liquor. Los Cuates is a beverage produced in the state of Coahuila, which is reflected in its composition differs from that of sotol produced in Chihuahua. Moreover, La Hacienda is the liquor which is used in more technology, reflected in a chemical composition that makes it different from other beverages tested. 


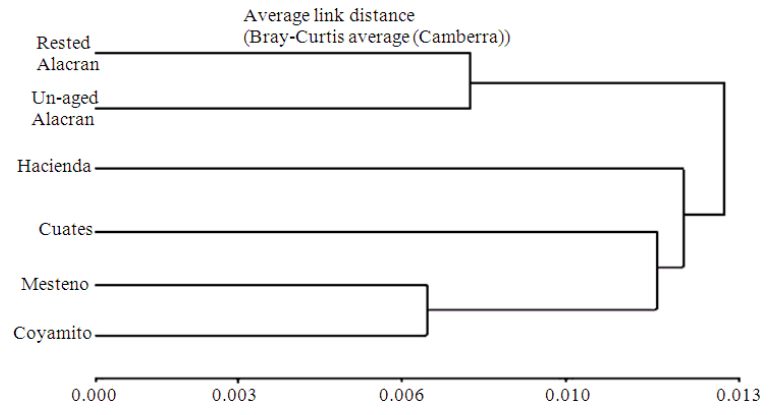

Fig.2: Conglomerate of six different liquors of sotol based on their chemical composition, using the average linkage method and the Bray-Curtis distance

\section{CONCLUSION}

The authenticity of alcoholic beverages is due to aromatic compounds that generate these different aromas and flavors, depending on the process and the type of pineapple used. The artisanal sotol contains acids and esters of higher molecular weight as undecanoic acid, of indicators for the characteristic flavor from distilled beverages from agaves and sotol, which are negatively correlated with the ethanol content of the product, thus establishing his absence as parameter sotol purity. There are differences in the concentration of compound such as ethyl acetate, propanol and allyl alcohol present in the artisanal and industrial sotol. This work sets the standard in the characterization of volatile compound in distilled alcoholic beverage known as sotol.

\section{ACKNOWLEDGEMENT}

Juan Buenrostro wants to thank to CONACYT for the scholarship assigned for his postgraduate studies in the program of Food Science and Technology, UAdeC. Authors thank the financial support of the program CONACYT-FONCYT-2008.

\section{REFERENCES}

Beech, F.W. and R.R. Davenport, 1970. The Role of Yeasts in Cider Making. In: Yeast Technology, Rose A.H. and J.S. Harrison (Eds.)., 1st Edn., Vol. 3, Academic Press, London, ISBN: 0125964153, pp: 73-146.

Berry, D.R. and D.C. Watson, 1991. Production of Organoleptic Compounds. In: Yeast Biotechnology, Berry, D., Russell, I. and G. Stewart (Eds.)., Allen and Unwin, London, ISBN: 0 40574042, pp: 471-500.
De la Garza-Toledo, H., M. Martinez, L. Lara, R. RodriguezHerrera, J. Rodriguez-Martinez and C.N. Aguilar, 2008. Production of a Mexican alcoholic beverage: Sotol. Res. J. Biol. Sci., 3: 566-571. DOI: 10.3923/rjbsci.2008.566.571

De Leon-Rodriguez, A., L. Gonzalez-Hernandez, A.P. Barba-de la Rosa, P. Escalante-Minakata and M.G. Lopez, 2006. Characterization of volatile compounds of Mezcal, an ethnic alcoholic beverage obtained from agave salmiana. J. Agric. Food Chem., 54: 1337-1341. DOI: 10.1021/jf052154

Dieguez, S.C., L.D. Diaz, M.L.G. De La Pena and E.F. Gomez, 2002. Variation of volatile organic acids in spirits during storage at low and room temperatures. LWT-Food Sci. Technol. 35: 452-457. DOI: $10.1006 /$ fstl.2001.0882

Fleet, G.H. and G.M. Heard, 1990. Yeast growth During Fermentation. In: Wine Microbiology and Biotechnology, Fleet, G.H. (Ed.)., Harwood Academic Pub., Switzerland, ISBN: 0415-278503, pp: 27-75.

Gutierrez-Coronado, M.L., E. Acedo-Felix and A.I. Valenzuela-Quintanar, 2007. Bacanora industry and its process of elaboration. Sci. Technol. Food, 5: 394-404. DOI: 10.1080/11358120709487718

Heard, G.M. and G.H. Fleet, 1985. Growth of natural yeast flora during the fermentation of inoculated wines. Applied Environ. Microbiol., 50: 727-728.

Heresztyn, T., 1986. Metabolism of phenolic compounds from hydroxycinnamic acids by Brettanomyces yeasts. Archives Microbiol., 146: 96-98. DOI: 10.1007/BF00690165

Lachenmeier, D.W., F. Kanteres, T. Kuballa, M.G. Lopez and J. Rehm. 2009. Ethyl carbamate in alcoholic beverages from Mexico (Tequila, Mezcal, Bacanora, Sotol) and Guatemala (Cuxa): Market survey and risk assessment. Int. J. Environ. Res. Public Health, 6: 349-360.

Lopez, M.G., 1999. Tequila Aroma. In: Flavor Chemistry of Ethnic Foods, Shaihidi, H. (Ed.)., Kluwer Academic/Plenum, NY., ISBN: 0306461242, pp: 211-217.

Mancilla-Margalli, N.A. and N.G. Lopez, 2002. Generation of Maillard compounds from inulin during the termal processing of Agave tequilana Weber Var. azul. J. Agric. Food Chem., 50: 806-812. DOI: 10.1021/jf0110295

Molina-Guerrero, J.A., J.E. Botello-Alvarez, A. EstradaBaltazar, J.L. Navarrete-Bolanos and H. JimenezIslas et al., 2007. Volatile Components in Mezcal. Revista Mexicana de Ingenieria Quimica, 6: 41-50. 
Pena-Alvarez, A., L. Diaz and A. Medina, 2004. Characterization of three agave species by gas chromatografy and solid-phase gas chromatografymass spectrometry. J. Chromatogr. A., 1027: 131-136. DOI: 10.1016/j.chroma.2003.10.082

Ribereau-Gayon, P., D. Dubourdieu, B. Doneche and A. Lonvaud, 2000. Biochemistry of Alcoholic Fermentation and Metabolic Pathways of wine Yeasts: In Handbook of Enology. In: The Microbiology of Wine and Vinifications, John Wiley and Sons Ltd. (Eds.)., Dunod, Paris, France, ISBN: 13: 978-0-470-01034-1, pp: 51-74.
Robertfroid, M.E. and N.M. Delzenne, 1998. Dietary fructtans. Ann. Rev. Nutr., 18: 117-143. 